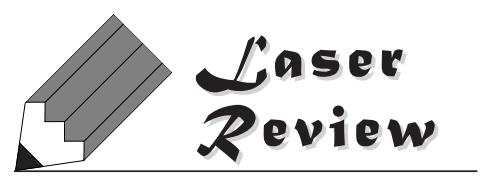

\author{
非線形ファイバを用いた超短光パルススクイージング \\ 武岡 正裕 $*$, 藤島 大輔 $* *$, 神成 文彦 $* *$ \\ * 通信総合研究所 ( 1 184-8795 東京都小金井市貫井北町4-2-1) \\ ** 慶應義塾大学 理工学部電子工学科 ( ₹ 223-8522 神奈川県横浜市港北区日吉3-14-1)
}

\title{
Ultrashort Optical Pulse Squeezing in Nonlinear Fibers
}

\author{
Masahiro TAKEOKA*, Daisuke FUJISHIMA**, and Fumihiko KANNARI** \\ * Communications Research Laboratory, 4-2-1 Nukui-Kitamachi, Koganei-city, Tokyo 184-8795 \\ ** Department of Electronics and Electrical Engineering, Keio University, 3-14-1 Hiyoshi, Kohoku-ku, Yokohama $223-8522$
}

(Received January 15, 2002)

\begin{abstract}
Concepts and experimental works of ultrashort optical pulse squeezing in nonlinear fibers are reviewed. In a nonlinear fiber, optical fields are squeezed or quantum mechanically correlated by optical Kerr effect. These are, however, unobservable by direct photo-detection. Three kinds of strategies to extract the detectable squeezing have been proposed and implemented experimentally. Recent studies on applications of these squeezed pulses or the intrapulse quantum correlations to the generation of entangled states are also reviewed.
\end{abstract}

Key Words: Squeezed state, Kerr effect, Ultrashort pulse, Soliton, Entanglement

\section{1.はじめに}

光の量子力学的特性を最大限に利用した, 量子通信, 超精密測定などの応用に関する研究が最近大きな注目を 浴びているが，モード同期レーザーによる超短パルス光 源とファイバの非線形性はこの分野でも有力なッールと なりつつある, 自己位相変調, 相互位相変調など3次の非 線形効果であるカー効果を用いた光のスクイージング, 量子非破壞測定などの理論的な提案は, 低損失な非線形 媒質である石英の光ファイバを使って実現することが期 待されてきたが，ファイバの持つ非線形係数は非常に小 さいため連続光を用いた実験はいずれも原理実証の段階 に留まっていた。しかしながらこれらの提案は, 強い ピークパワーを持つ超短パルス光の技術，とりわけソリ トン伝搬の活用によってこの10年の間に定量的にも目に 見える成果として現れるようになってきた。また近年で は，単に単一モード光に扔ける理論を実現するだけでな く, 超短パルスの持つ広帯域なスペクトルを生かした, 新しいスクイージングの手法や概念なども生まれつつあ る.

本稿では, カー効果による光の量子状態の変化を簡単 に述べた後, 超短パルスとファイバを用いた量子光学に ついて，スクイズド状態生成に関する研究を中心にその 原理，これまでの成果を紹介寸る。また最後に，その応 用に関する最近の話題，とりわけ量子光学の応用上最も 重要な概念の一つといわれる量子エンタングルメント（も
つれ合い状態)生成への取り組みとその展望などにも触れ る.

\section{2. 単一モード 光の光カー効果とスクイズド状態の生成}

量子力学的には, 光の状態も波動関数で表される. 光 の振幅や位相などの量を測定する際に現れる量子摇らぎ の大きさは, 波動関数の絶対值の 2 乗で表される状態の確 率分布によって決まっている，また，例えば光波のsine成 分と cosine成分, 光子数と位相などは互いに非可換な量の 組であり，それぞれの量子摇らぎの間には不確定性原理 を満たす必要がある。その不確定性原理を破ることなく これらの測定量のうち片方のみをショット雑音以下に圧 搾(スクイズ)した状態はスクイズド状態と呼ばれ，特に先 の例では前者は直交位相振幅スクイズド状態, 後者は光 子数スクイズド状態 (または位相スクイズド状態)などと 呼ばれている2). 光のスクイズド状態はパラメトリック変 換などの非線形過程によって生成され，そのような量子 摇らぎの制御された状態は, 従来の量子雑音限界を超え る超高感度な測定などへの応用が期待されている他 ${ }^{3)}$, 量 子テレポーテーション4)をはじめ近年の量子光学の応用に おける最も重要な概念である量子エンタングルメント(も つれ合い状態)生成のためのッールとしても注目されてい る.

ファイバをはじめとする光カー媒質においても同様に スクイズド状態が生成される。 Fig. 1は，コヒーレント状 


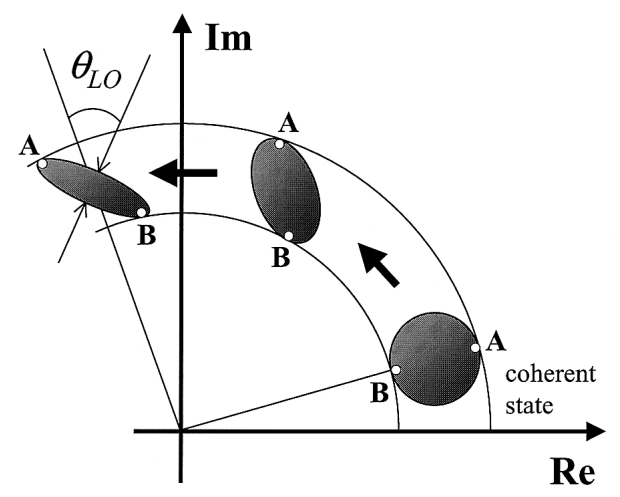

Fig. 1 Phase diagram for the sate evolution of the optical field in Kerr media. The shaded area indicates the quantum fluctuation of the field.

態の単一モードレーザー光がカー媒質を伝搬した場合の 位相空間上における量子摇らぎの発展を表しており，量 子摇らぎは三日月形にスクイズされていくことがわか る5＊。このようなスクイージングの起きる過程は, 次の ように説明できる、単一モード光に対するカー効果は, 自身の電界振幅の2乗, つまり強度に比例した位相変調 (自己位相変調)として現れる。ところが，コヒーレント状 態の光の波動関数は電界振幅に対しある拡がりを持って 分布しているため, Fig. 1のA点, B点のように振幅の大き な部分では強い位相変調, 小さな部分では弱い位相変調 がかかってスクイージングが起こるのである.

これは光の状態の波動関数と自己位相変調の時間発展 演算子を用いて厳密に解析することができる。自己位相 変調による量子力学的な状態の時間発展演算子は

$$
\hat{U}(t)=\exp \left[-i \hat{H}_{I} t / \hbar\right]=\exp [-i \chi \hat{n}(\hat{n}-1) t]
$$

で表される。ここで^は演算子であることを表し，また $\chi$ は媒質の3次の非線形感受率に比例した量である。(1)式を 用いると, コヒーレント状態 $\left|\alpha_{0}\right\rangle$ の時間発展は, $\left|\alpha_{0}\right\rangle$ を光 子数状態で展開することにより,

$$
\begin{aligned}
\hat{U}(t)\left|\alpha_{0}\right\rangle & =\hat{U}(t) \exp \left[-\left|\alpha_{0}\right| / 2\right] \sum_{n} \frac{\alpha_{0}^{n}}{\sqrt{n !}}|n\rangle \\
& =\exp \left[-\left|\alpha_{0}\right| / 2\right] \sum_{n} \frac{\alpha_{0}^{n}}{\sqrt{n !}} \exp [-i \chi n(n-1) t]|n\rangle
\end{aligned}
$$

と表される．明らかにそれぞれの光子数状態に対しnに依 存した異なる位相変調がかかっており, 先程の説明と一 致する. ただし, カー効果が光子数状態そのものを恋え ていないことに注意する必要がある.このことは, 光子 数状態の重ね合わせであるコヒーレント状態は変調され ているが，光子数分布自体は変わらない，つまり状態の 光子数が保存されることを意味する. 実際, 単一モード のカー効果は吸収損失などの散逸を含まない相互作用で
あるからこれは当然のことである。このため，ファイバ を通過した光の出力を直接フォトダイオードなどの検出 器で受けても光子数分布の変化やスクイージングが観測 されることは無い. 生成された直交位相振幅スクイズド 状態は信号に対し十分強度のある局部発振光 (LO光)を適 切な位相で干渉させてホモダイン検出を行うことによ り, 検出器への出力へと射影させることができる. Fig. 1 の例では, スクイージングを検出するための局発光の位 相は $\theta_{\mathrm{LO}}$ である。

\section{3. 超短パルスを用いたスクイズド状態の生成}

光ファイバを用いたスクイージングは， $2 \mathrm{~K} に$ 冷却され たファイバと連続光レーザーを用いて1987年に初めて検 出されたが，それは-1 dBに満たないわずかなものだっ た7．しかし1990年代に入り，実験は全てパルス光源を用 いて行われるようになった。超短パルスが用いられた理 由は, 主として鋭いピークパワーによりカー効果の非線 形性のみを増強して単一モード光での理論を実現するこ とにあった。しかし近年ではパルスの広帯域なスペクト ルを生かした独自の現象も研究されつつある，以下で は，まずファイバを伝搬する際の超短パルスと単一モー ドとの類似や相違について触れた後，スクイズド状態生 成法をその原理によって3種類に分類し, それぞれの原理 とこれまでの成果を紹介する。

\section{1 超短パルスのファイバ伝搬}

スクイズド状態生成をはじめ量子光学の理論において 連続光とパルスで重要な相違点は，前者が単一モードで あるのに対し後者はあるスペクトル帯域を持つ，すなわ ち多モードであることにある。前述のカー効果によるス クイージングの理論をパルス光を用いて実践しようとし た場合，パルス全体を一種の単一モード光とみなす。こ のようなパルスのスクイズド状態は，パルス内のスペク トル波形全体を位相，振幅を乱すことなく測定すること により検出される。具体的には，LO光として用いるパル スがどれだけ正確にこのスクイズド状態を射影できるか ということに相当し，実際には伝搬中の周波数チャープ や空間モードのずれなどによる信号パルスとLOパルス波 形の不整合がスクイージングの検出を制限する一因とな る場合がある。

実際の実験では, 強いピークパワー, 伝搬波形の保持 という2点を満たす上で異常分散波長帯におけるソリトン パルスは非常に有効である。これまで多くの実験は, 波 長1.5 $\mu \mathrm{m}$ 帯のソリトンパルスか, 波長 $1.3 \mu \mathrm{m}$ 帯や分散シフ トファイバなどを用いた無分散領域で行われてきた。 1.3 $\mu \mathrm{m}$ 帯の利点は，短波長の方がモード断面積が小さくなり 非線形性が増すことや，実験が行われた当時 $1.5 \mu \mathrm{m}$ 帯より も高い量子効率の受光器が存在したことなどが挙げられ

\footnotetext{
*Fig. 1では量子摇らぎの分布が楕円形に書かれているが厳密には三日月形であり, 通常の直交位相振幅スクイージングなどとは異なる 性質を持つ5). しかしながら，ここで扱うファイバ実験では伝搬光の光子数は十分多く $\left(\langle n\rangle>10^{8}\right)$ 量子摇らぎの線形近似 $\left.{ }^{6}\right)$ が可能なた め，楕円で表される直交位相振幅スクイズド状態と近似的にみなすことができる.
} 
るが，パルス伝搬中の周波数チャープによるLOパルスと の不整合がスクイージングの限界を決めてしまうため, 最近では多くの実験が $1.5 \mu \mathrm{m}$ 帯のソリトンパルスで行われ るようになっている。

一方理論では, ファイバ中のパルス伝搬の量子論的な 扱いは単一モードの場合に比べ格段に複雑になる。カー 効果は各モード間に相互位相変調として現れるため, 波 動関数を厳密に調べようとすると多体効果としての扱い が必要となりその解析は非常に困難になると予想され る。一般にはMaxwellの伝搬方程式を量子化した演算子の 運動方程式で扱われることが多い8). 以下に紹介する理論 計算でも, 運動方程式の線形近似や統計微分方程式によ る計算を行いガウス近似した量子摇らぎの分散を求めて いる。また，ソリトン波形が扱われている場合，量子ソ リトンという記述が多くあるが，本稿のように単にソリ トンを用いて量子効果を扱っている研究と, ソリトンを 一種の粒子的なものと見なしてその固有状態などを探索 する研究を指す場合があるので注意が必要である. 後者 に関しては，文献9)などに詳しく述べられている。

\section{2 対称ファイバ干渉計による真空スクイズド状態 の生成と検出}

パルスによる最初の実験10,11)で用いられたのは，1990年 にShirasakiら ${ }^{12)} に よ り$ 提案された対称な非線形干渉計を用 いる方法で，また2001年には現在までのファイバによる 最も大きなスクイージング $(6.2 \pm 0.1 \mathrm{~dB})$ もこの方法とソ リトンパルスを用いて達成されている13). Fig. 2(a), (b) に，その概念図と実験装置例を示す。はじめコヒーレン 卜状態にある入射パルスはビームスプリッターにより50: 50 に分割され，同一のカー媒質により構成されたMachZehnder干渉計のそれぞれの腕でスクイズされる. 干渉計 の出口にはやはり50:50のビームスプリッターがあり，2つ のポートに対してそれぞれconstructive, destructiveな干渉が 起こるように位相を合わせる。すると後者のポートで は, スクイズされた真空状態が作り出される。この真空 スクイズド状態は, 前節で述べたように同一の光源から 用意したLOパルスを用いれば，ホモダイン測定によって 検出することが可能である．技術的には，良いスクイー ジングを得るためには干渉計の対称性に厳しい精度が要 求される一方, 干渉計によって光源自体の持つ雑音が キャンセルされるというメリットもある。これまでの研 究のレビューは, 文献14)などが詳しい. 例えば1.3 $\mu \mathrm{m}$ に おける実験では, 既に- $5.1 \mathrm{~dB}$ のスクイージング15)が検出 されている. 検出器の効率 $(85 \%)$ を考慮に入れると, こ れは理論的に予想されているLOパルスとの不整合による 限界にほぼ到達していることがわかっている。また低複 屈折ファイバを用いて, 直線偏光のパルスとそれに直交 した真空の間の相互位相変調を利用した方法 ${ }^{16,17)}$ なども提 案されている.

ところでファイバ中では, カー効果以外にもブリルア ン散乱, ラマン散乱などの非線形効果も存在する1)。これ らの中で超短パルスのスクイージング全般において障害 となるのは, 主として導波音響波ブリルアン散乱 (Guided

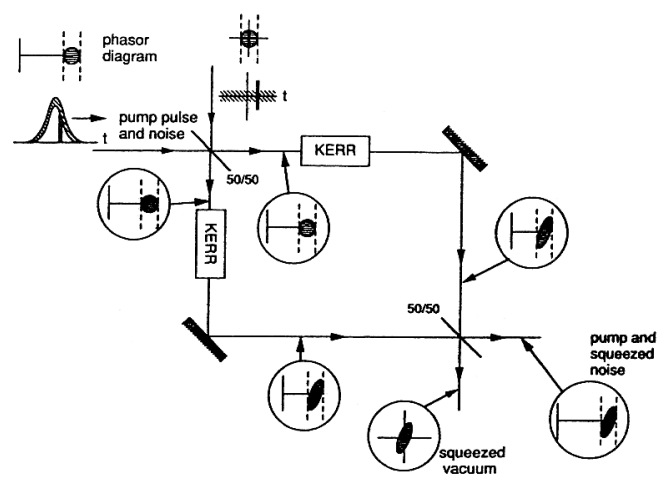

(a)

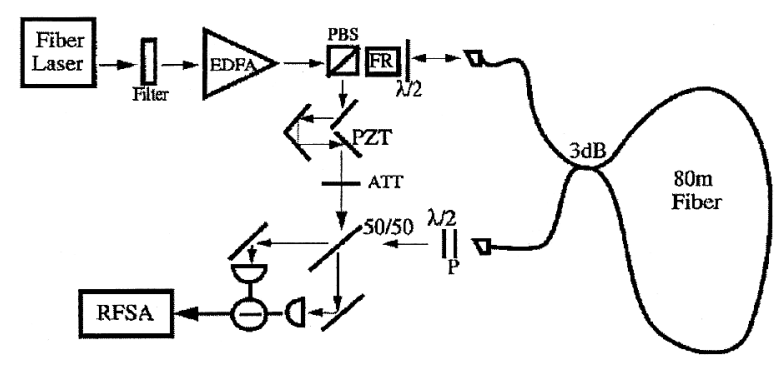

(b)

Fig. 2 (a) Schematic of the squeezed vacuum generation in a symmetric nonlinear Mach-Zehnder interferometer. $^{11)}$ (b) Experimental setup. ${ }^{13)}$

Acoustic-Wave Brillouin Scattering: GAWBS) ${ }^{18)}$ と誘導ラマ ン散乱 (Stimulated Raman Scattering: SRS) 19)の2種類であ る. GAWBSの周波数は石英ファイバでは一般に約 $20 \mathrm{MHz}$ 〜 $1 \mathrm{GHz} ゙$ あ，スクイズド状態の測定周波数やパルスの 繰り返し周波数などと重なる.GAWBSを回避するために は, ピークとピークの間の周波数を選べばよいが, 影響 の無い低周波数 $(\sim 100 \mathrm{kHz})$ で測定する10,11,20)，2つのパル スを用いてGAWBSを相殺する21), 繰り返し周波数を GAWBSの分布する周波数より大きくする ${ }^{13,15)}(>1 \mathrm{GHz})$ などの工夫が検討されてきた。また，パルス幅とファイ バ長が十分に短くてもGAWBSの影響は抑圧される。スク イージングへの影響の詳細な解析は, 文献18,22) などに詳 しい. 一方SRSは, 0 約 $40 \mathrm{THz}$ の周波数に分布して 13 THz 付近に強いピークを持っているため, 1 psを切るよう なフェムト秒パルスにおける周波数シフトや波形の歪み を生じさせる.フェムト秒パルスの実験では, 一般的に SRSによるスクイージングの劣化と思われる結果が得られ ているが，後述のように必ずしも悪く働くとは限らない 場合もあるようである.

\section{3 スペクトルフィルターを用いた光子数スクイー ジング \\ ファイバ中を伝搬するパルスは波長分散とカー効果を} 受ける。このときパルス内ではパルス幅，エネルギー， またファイバ長などに依存して非線形にスペクトルの拡 がりや狭まりが起こる。そのため伝搬後のパルスに対 し，スペクトルに対称で中心周波数付近を透過させるよ 
うなフィルターをかけると，そのときの損失は入射エネ ルギーに非線形に依存する。よってこのような系はFig. 3 (a)に示すようなエネルギーに対する非線形な入出力特性 を持ち, そのスロープのなだらかな部分は強度摇らぎの 安定化をもたらす。この現象が量子摇らぎについても適 用される，すなわちパルスの光子数摇らぎがスクイズさ れることは，1995,6年にFribergら 23,24)によるソリトンパル スを用いた実験で初めて報告された。その実験装置図を Fig. 3 (b) に示す。標準量子限界のキャリブレーションは, 減衰されてほぼコヒーレント状態にあるレーザー光の測 定や，信号パルスを50:50のビームスプリッターで分割し てその測定電流の差の分散を測定することなどにより行 われた。

この手法は連続光ではなくパルスを用いて初めて可能 となり, また入出力の光子数が保存しないという点で先 の干渉計のスキームと本質的に異なる.さらに次の点で 興味深い. まず光子数を直接検出すればよいためLO光が 必要無い.よって実験系は簡単になる。またLO光との干 渉が必要無いためGAWBSによる位相摇らぎの影響も受け にくくなると考えられ, さらに伝搬パルスの周波数

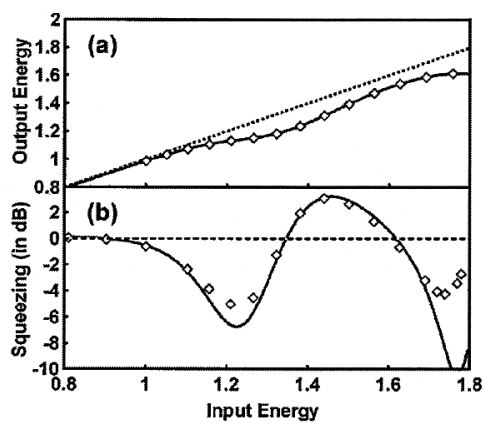

(a)

(b)

Fig. 3 (a) Theoretical calculations of the energy transfer and the quantum noise transfer characteristic for spectrally filtered soliton pulses. ${ }^{24)}$ These are calculated from the heuristic model (solid lines) and the quantum field-theoretical model (rectangular markers). The dotted line corresponds to the standard quantum limit. (b) Experimental apparatus. ${ }^{24)}$

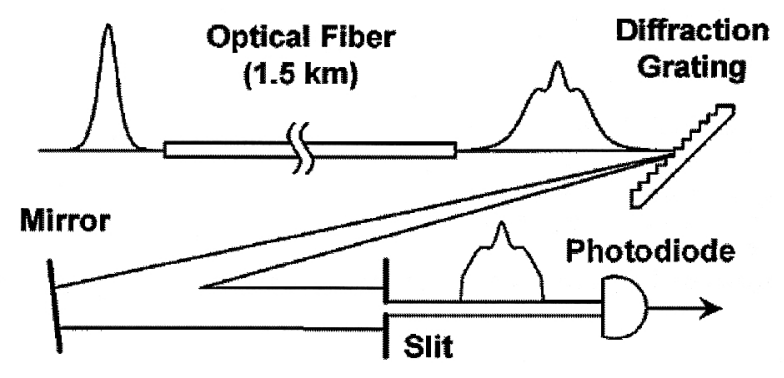

チャーピングもスクイージング検出限界の本質的要因で は無くなる25)。ただし, 鋭いピークパワーを保持すると いう点でソリトンの利点は大きく，これまでで最大のス クイージング $(3.8 \pm 0.2 \mathrm{~dB})$ はソリトンパルスで得られて いる26).また，この実験ではパルス幅 $130 \mathrm{fs}$ の光源が用い られたが， $3.8 \mathrm{~dB}$ のスクイージングはSRSによる周波数の ラマンシフトが十分起こるような長い伝搬距離におい て, 周波数非対称なhigh-pass フィルターによって観測され ているという点も興味深い. 短い伝搬距離では理論的に 予測されていなかったような，カー効果とSRSの複合的な 効果によるスクイージングの可能性がある。長い距離の 非線形伝搬の数值計算が困難であり，定性的な説明など が試みられている27)が，必ずしも明らかでない部分も 残っている。スペクトルフィルタリングのこれまでの主 な実験, 理論の結果をTable 1 に示す.

\section{4 非対称ファイバループ干渉計によるスクイー ジング}

この方法は基本的には先述の単一モードの理論的研究5) において既に提案されていた方法であるが，比較的簡単 な実験装置であり，またスペクトルフィルタリングを複 合的に含んでいる可能性も示唆されている点でも興味深 い. 名前の通り，Fig. 2（a）において対称に分割したパル スのエネルギー比を著しく非対称にすることによりスク イズド状態が得られる。このとき強いパルスの量子摇ら ぎはカー効果によりスクイズされているが，もう一方の 補助的なパルスは強度が弱いためカー効果の影響をほと んど受けない.干渉計の出口でも同様に分割比の非対称 なビームスプリッターを用いて同位相でこれらを干渉さ せると, Fig. 4 (a)のような出力が得られる. 強いモード の量子摇らぎはスクイズされているが, その角度は補助 的なモードによって実効的に回転させられていることが わかる。この回転を適切に選べば出力は直接検出可能な 強度に対するスクイズド状態**となり, 実験は比較的容 易になる，補助的なモードは，いわばLO光の役割を果た しているとも言える。補助的なモードはほぼコヒーレン ト状態にあるため強いモードのスクイージングを幾分劣 化させるが，ビームスプリッターの分割比が十分小さけ ればその影響は非常に小さい. カー効果と分散のみを含

Table 1 Experimental and theoretical results for the squeezing by the spectral filtering. NR is the noise reduction (squeezing) ratio.

\begin{tabular}{|c|c|c|c|}
\hline year & $\mathrm{NR}[\mathrm{dB}]$ & fiber length & pulse \\
\hline \multicolumn{4}{|l|}{ experiment } \\
\hline $1996^{24)}$ & -2.3 & $1.5 \mathrm{~km}$ & $2.7 \mathrm{ps}(N=1.2)$ \\
\hline $1998^{26)}$ & -3.8 & $90 \mathrm{~m}$ & $135 \mathrm{fs}(N=1.3)$ \\
\hline theory & & Raman scattering & \\
\hline $1997^{28)}$ & -6.5 & without SRS & $N=1$ soliton \\
\hline $1996^{29)}$ & -6.8 & without SRS & $N=1.1$ soliton \\
\hline $1996^{29)}$ & -4.3 & with SRS & $N=1$ soliton \\
\hline
\end{tabular}

**ここでも, 本来は厳密な意味での光子数スクイズド状態に相当する三日月型のスクイージングが形成されるが，光子数の十分多い 実際の実験では楕円型のスクイージングとみなして構わない. 


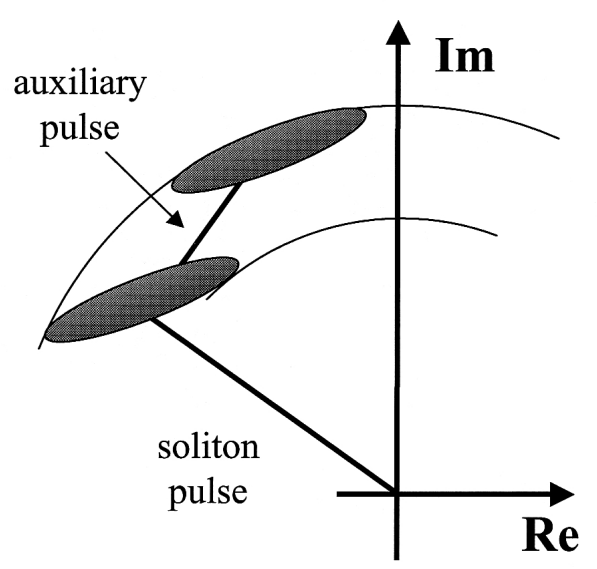

(a)

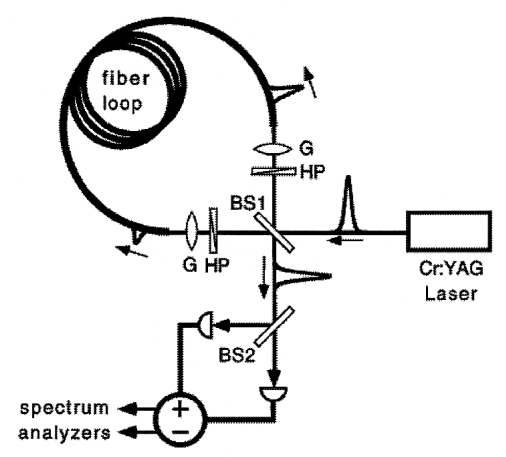

(b)

Fig. 4 (a) Phase diagram of the photon-number squeezing from an asymmetric nonlinear interferometer. (b) Experimental setup. ${ }^{32)}$

めた理論解析では, 強いモードに $N=1$ の基本ソリトンパ ルスを用いた場合，スクイージングの限界は補助パルス の分散と干渉計の損失 (分割比で決まる未使用のポートへ の出力)で決まり, 比較的短い伝搬距離でも $-13 \mathrm{~dB}$ 以上の スクイージングが可能であることが示されている30)。ま た対称干渉計の場合と比べると, ビームの分割比に対し てスクイージングは非常にinsensitiveであるため, 安定に スクイズド状態が得られるといった技術的な利点も大き い(ただし, 光源の雑音はほぼショット雑音レベルである ことが要求される).

さらにこの方法では，パルスを用いることによってス ペクトルフィルタリングの効果も期待されているところ が興味深い.この干渉計では, 片腕でのみ起こるカー効 果の非線形位相変調により, 干渉計が入出力エネルギー に関して非線形な応答を示すことがスクイージングに寄 与しているが，パルスの場合先述のようにスペクトル幅 も非線形に変化することから，スペクトル波形の干渉に おいても非線形な入出力関係が得られスクイージングに 寄与し得る.この効果が最適化されれば, 先に述べたス クイージングの限界のうち損失によるものを超えられる 可能性がある。このような特徵は実験的にはまだ明確に 確認されていないが, 数值計算によっては示唆されてい る31).
実際の実験は，例えばFig. 2 (b)のようなファイバルー プ干渉計を用いて行われる ${ }^{32,33)}$. 2つのパスを同一のファ イバにすることによって，2つのパルスの空間モードや位 相のマッチングは容易になる。またファイバの 2 方向の向 きではなく, 同一方向の $2 つ の$ 偏光状態を用いて干渉計を 構成する方法 ${ }^{34,35)}$ も提案されており, ビーム分割比の最適 化やシステムの簡単化など, より汎用性のあるデバイス としての最適化の追求が続けられている手法である。こ れまでの主な研究成果をTable 2 に挙げる.

\section{4. パルス内部の多モード 量子相関とその制御}

ところで，スペクトルフィルタリングの手法について もう少し量子論的に考えてみる。スクイージングは，パ ルスのスペクトル全体を測定することにより観測され る，いわば多モードスクイージングである。さらにフィ ルタリングによってある周波数成分を除去 (トレースアウ 卜)することにより光子数スクイージングが起こるため, ファイバ伝搬中に, フィルターを透過するスペクトル成 分同士の間や透過される成分とカットされる成分の間に ある種の量子相関が形成されることが本質的であると考 えられる。このような予想に基づき, Spaelterら ${ }^{37)}$ はファ イバ伝搬後のパルスを複数のスペクトルに分解し，その うちの $2 つ の$ 周波数成分間の光子数相関を測定してマッピ ングし，透過させる周波数に対し正の相関を持つ部分を なるべく除去し，互いに負の相関を持つ成分同士を取り 出すことによって最適なスクイージングが得られること を実験的に実証した(フィルターの厳密な最適化に関して は，文献38)で理論解析されている).

このような周波数モード間の量子相関は, 量子光学の ための新しい光源として利用できる可能性がある．筆者 らはこの視点に基づいて，ファイバ入射前の超短パルス 波形を(古典的に)整形することにより，伝搬後のパルス内 部の量子相関を制御するシステムを提案し，その評価と してスペクトルフィルタリングによる光子数スクイージ ングの最適化を数值計算で示した ${ }^{39)}$. Fig. 5 (a)に光子数 スクイージング最適化に想定される実験装置図を示す。 超短パルスは, ファイバ入射前にFourier波形整形器40)に よってスペクトル整形される. また測定された光子数分 散のデータは計算機に送られ，適応制御アルゴリズムを 用いて波形整形器のマスク設計のためにフィードバック

Table 2 Experimental and theoretical results for the squeezing by asymmetric nonlinear fiber interferometers. NR is the noise reduction (squeezing) ratio.

\begin{tabular}{ccccc}
\hline \hline year & $\begin{array}{c}\text { NR } \\
{[\mathrm{dB}]}\end{array}$ & $\begin{array}{c}\text { fiber } \\
\text { length }\end{array}$ & $\begin{array}{c}\text { pulse } \\
\text { (soliton) }\end{array}$ & $\begin{array}{c}\text { splitting } \\
\text { ratio }\end{array}$ \\
\hline $\begin{array}{c}\text { experiment } \\
\left.1998^{32}\right)\end{array}$ & -3.9 & $6.4 \mathrm{~m}$ & $126 \mathrm{fs}(N=1)$ & $90: 10$ \\
$1998^{33)}$ & -5.7 & $10 \mathrm{~m}$ & $182 \mathrm{fs}(N=1.85)$ & $82: 18$ \\
$2001^{34)}$ & -4.4 & $6 \mathrm{~m}$ & $180 \mathrm{fs}(N=1.6)$ & $68: 32$ \\
theory & \multicolumn{5}{c}{ Raman scattering } \\
$1998^{36)}$ & -8.7 & with SRS & $N=1.85$ & $90: 10$ \\
$1999^{30)}$ & -13.7 & without SRS & $N=1.1$ & $96: 4$ \\
$2000^{31)}$ & -13 & without SRS & $N=1.1$ & $90: 10$ \\
\hline \hline
\end{tabular}




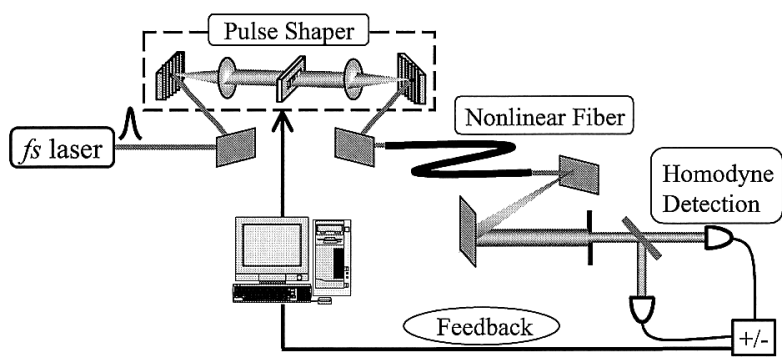

(a)

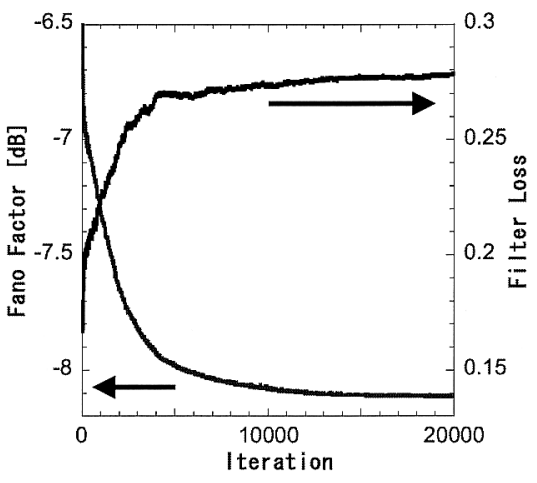

(b)

Fig. 5 (a) Optimization control scheme for the photon-number squeezing by the spectral filtering. ${ }^{39)}$ (b) $\mathrm{Nu}-$ merical simulation of the optimization of the squeezing for the $N=1$ soliton pulse. The fiber distance and the normalized cutoff frequency are 3 soliton periods and \pm 0.73 , respectively. ${ }^{39)}$

される。このような適応制御システムは, 超短パルス励 起による分子の化学反応制御や原子の量子状態制御など で既に適用されているが41)，パルスの量子状態そのもの への適用はおそらくこれまでにない試みである。Fig. 5 (b) はシステムの数值計算による評価結果であり，横軸の フィードバック回数を重ねるにつれ，スクイージングが 最適值へと収束していく様子がわかる。この計算では, 従来- $6.5 \mathrm{~dB}$ のスクイージングが限界と予想されていた $N=$ 1ソリトンのエンベロープで- $8 \mathrm{~dB}$ 以上のスクイージング が可能となることが示された。このシステムはより複雑 な量子相関の生成が可能であると予想され，パルス内の 周波数モード間の直交位相振幅エンタングルメントな ど，応用可能で，かつ従来考えられてこなかった新しい 量子状態の生成が可能となることが数值計算により確か められつつある。

\section{5. 量子光学応用への展望}

最後に，これらのカー効果によるスクイズド状態を 使った応用への試みを紹介する。まず，カー効果は古く から量子状態を変化させること無く測定する量子非破壊 測定に使えることが考えられていた。パルスを用いた実 験も行われており文献14,42) などでレビューされている. また，干渉計で生成されたスクイズド状態がショット雑
音を超える精度での干渉計測を可能とすることなども提 案されており ${ }^{43)}$ ，実験でも実証されている21).

また最近では，量子エンタングルメントと呼ばれる量 子状態間 (特に光モード間)の非局所的な量子相関が，量子 計算，量子暗号，量子通信や計測などの研究で最も重要 な概念のひとつとして考えられている44,45). 光のエンタン グルメントはこれまで，2次の非線形結晶を用いた自然放 出パラメトリック下降変換による光子対生成 ${ }^{44)}$ や，パラ メトリック共振器から生成された単一モードスクイズド 光の重ね合わせ46)により実現されてきたが，単一モード の理論とのアナロジーから, ファイバ中でも3次非線形性 のパラメトリック過程による光子対生成が提案された り47)(パラメトリック増幅による相関は実験で観測されて (る $\left.{ }^{48)}\right)$ ，非対称干渉計で生成されたソリトンスクイズド パルスによるパルスのエンタングルメントの生成49)が実 現されている。特に後者のようなパルスのエンタングル メントは，多数の光子を含むマクロな光の波数空間では なく実空間に局在したエンタングルメントという点で新 規性があり，これを用いて実空間局在した連続量量子波 束のテレポーテーションなどが実現されればインパクト は非常に高いだろう。また，光子対生成と比べると非常 に高い生成効率を持ち，単一モード生成の方法に比べれ ば装置や要される技術ノウハウが非常に少ないという大 きな魅力を持つ。一方で，ピークパワーの強いパルスに できたエンタングルメントをテレポーテーションなどに 応用しようとする場合，その信号パルスよりも十分に強 いLOパルスが必要となる場合が多く検出器の飽和が問題 となる。ホモダイン検出の方法論や，またはLOを必要と しない観測量におけるエンタングルメント生成の可能性 など，何らかのブレークスルーが必要と考えられる。 ファイバ系が簡便なエンタングルメント生成の光源とし て発展するには, レーザー, ファイバや検出器の研究者 と量子光学，量子情報の研究者の間での交流が重要であ ろう。また理論的にも，演算子表示と非線形な数值計算 を主体とする解析と，状態の正確な波動関数の表示を好 む(そして必要とする) 量子情報分野の理論との間の隔たり を埋める努力が必要である。応用の具体的な例として は，ソリトンパルスのエンタングルメントの利用を想定 した量子暗号プロトコル50)などが提案されはじめてい る.

紙面の都合上，古典的な非線形光学や技術的な事柄に 関する話題は最小限にとどめ，量子効果の原理の説明に 主題をおいた。しかしこれらの基礎的な考察にレーザー 研究者の最新の技術を融合させることによって新しい研 究が芽生えれば幸いである。

\section{参考文献}

1) G. P. Agrawal: Nonlinear Fiber Optics, 2nd edition (Academic Press, San Diego, 1995).

2) 松岡 正浩: 量子光学 (東京大学出版会, 東京, 1996年). スクイズド光の性質, 発生, 検出など, 実際の実験例も含め て広く記述されている。

3) M. Teich: Physics Today, June 26 (1990).

4) A. Furusawa, J. L. Sorensen, S. L. Braunstein, C. A. Fuchs, H. J. 
Kimble, and E. S. Polzik: Science 282 (1998）706 とその参考文 献など.

5) M. Kitagawa and Y. Yamamoto: Phys. Rev. A 34 (1986) 3974.

6) G. J. Milburn, M. D. Levenson, R. M. Shelby, S. H. Perlmutter, R. G. DeVoe, and D. F. Walls: J. Opt. Soc. Am. B 4 (1987) 1476.

7) R. M. Shelby, M. D. Levenson, S. H. Perlmutter, R. G. DeVoe, and D. F. Walls: Phys. Rev. Lett. 57 (1986) 691.

8）例えばS. J. Carter: Phys. Rev. A 51 (1995) 3274 とその参考文献 など.

9) 山本 喜久, 渡部仁貴：量子光学の基礎(培風館, 東京, 1994 年).

10) M. Rosenbluh and R. M. Shelby: Phys. Rev. Lett. 66 (1991) 153

11) K. Bergman and H. A. Haus: Opt. Lett. 16 (1991) 663.

12) M. Shirasaki and H. A. Haus: J. Opt. Soc. Am. B 7 (1990) 30.

13) C. X. Yu, H. A. Haus, and E. P. Ippen: Opt. Lett. 26 (2001) 669

14) A. Sizmann and G. Leuchs: Progress in Optics 39 (1999) 373.

15) K. Bergman, H. A. Haus, E. P. Ippen, and M. Shirasaki: Opt. Lett. 19 (1994) 290.

16) L. Boivin and H. A. Haus: Opt. Lett. 21 (1996) 146.

17) M. Margalit, C. X. Yu, E. P. Ippen, and H. A. Haus: Opt. Express 2 (1998) 72.

18) K. Bergman, H. A. Haus, and M. Shirasaki: Appl. Phys. B 55 (1992) 242.

19) S. J. Carter and P. D. Drummond: Phys. Rev. Lett. 67 (1991) 3757.

20) N. Nishizawa, S. Kume, M. Mori, T. Goto, and A. Miyauchi: Jpn. J. Appl. Phys. 33 (1994) 138.

21) N. Nishizawa, Y. Matsuo, M. Mori, T. Goto, and H. Nishimoto: Opt. Rev. 4 (1997) 453.

22) Bergman, C. R. Doerr, H. A. Haus, and M. Shirasaki: Opt. Lett. 18 (1993) 643

23) S. R. Friberg, S. Machida, and A. Levanon: Proceedings of Conf. on Lasers and Electro-Optics, CLEO/Pacific Rim 95, Chiba, July, 1995, TuF2

24) S. R. Friberg, S. Machida, M. J. Werner, A. Levanon, and T. Mukai: Phys. Rev. Lett. 18 (1996) 3775.

25) F. Koenig, S. Spaelter, I. L. Shumay, A. Sizmann, Th. Fauster, and G. Leuchs: J. Mod. Opt. 45 (1998) 2425

26) S. Spaelter, M. Burk, U. Stroessner, A. Sizmann, and G. Leuchs: Opt. Express 2 (1998) 77.

27) M. J. Werner: Phys. Rev. A 60 (1999) R781.

28) A. Mecozzi and P. Kumar: Opt. Lett. 22 (1997) 1232.
29) M. J. Werner: Phys. Rev. A 54 (1996) R2567.

30) D. Levandovsky, M. Vasilyev, and P. Kumar: Opt. Lett. 24 (1999) 89.

31) J. Higuchi, N. Nishizawa, M. Mori, K. Yamane, and T. Goto: Jpn. J. Appl. Phys. 39 (2000) 6243.

32) S. Schmitt, J. Ficker, M. Wolff, F. Koenig, A. Sizmann, and G. Leuchs: Phys. Rev. Lett. 81 (1998) 2446.

33) D. Krylov and K. Bergman: Opt. Lett. 23 (1998) 1390.

34) M. Fiorentino, J. E. Sharping, and P. Kumar: Phys. Rev. A 64 (2001) R031801.

35) J. Higuchi, N. Nishizawa, M. Mori, K. Yamane, and T. Goto: Jpn. J. Appl. Phys. 40 (2001) L1220.

36) M. J. Werner: Phys. Rev. Lett. 81 (1998) 4132.

37) S. Spaelter, N. Korolkova, F. Koenig, A. Sizmann, and G. Leuchs: Phys. Rev. Lett. 81 (1998) 786.

38) D. Levandovsky, M. Vasilyev, and P. Kumar: Opt. Lett. 24 (1999) 43.

39) M. Takeoka, D. Fujishima, and F. Kannari: Opt. Lett. 26 (2001) 1592.

40) K. Takasago, M. Takekawa, M. Suzuki, K. Komori, and F. Kannari: IEEE J. Select. Topics in Quantum Electron. 4 (1998) 346.

41）神成 文彦，武井信達，塩澤麻理子：レーザー研究 28 (2000) 479

42) P. D. Drummond, R. M. Shelby, S. R. Friberg, and Y. Yamamoto: Nature 365 (1993) 307.

43) M. Shirasaki and H. A. Haus: Opt. Lett. 17 (1992) 1225.

44) レーザー研究 第28巻 10 号「最近の量子光学の進展」特集号.

45) 数理科学 2001年6月号 No.456 特集：量子情報と量子コン ピュー夕.

46) L. J. Wang, C. K. Hong, and S. R. Friberg: J. Opt. B: Quantum Semiclass. Opt. 3 (2001) 346.

47) Z. Y. Ou, S. F. Pereira, and H. J. Kimble: Appl. Phys. B 55 (1992) 265.

48) J. E. Sharping, M. Fiorentino, and P. Kumar: Opt. Lett. 26 (2001) 367.

49) Ch. Silberhorn, P. K. Lam, O. Weiss, F. Koenig, N. Korolkova, and G. Leuchs: Phys. Rev. Lett. 86 (2001) 4267.

50) Ch. Silberhorn, N. Korolkova, and G. Leuchs: LANL eprint arXiv: quant-ph/ 0109009.
光パルススクイージング (optical pulse squeezing)

光の直交位相振幅, 光子数-位相など非可換な物理量の

うち一方の量子摇らぎを標準量子限界以下に抑制する技

術を，光のスクイージングと言う。光パルスは連続光に

比べ強いピークパワーを持つため，スクイージングに必

要な非線形光学効果を効率的に起こすことができるメ
リットがある。またスクイズされた光は，単に摇らぎが 少ないというだけでなく，量子エンタングルメント（もつ れ合い状態)を初めとした量子力学特有の状態の生成にも 使われ，量子情報処理，量子通信などの新しい技術への 応用が期待されている。

(武岡 正裕) 